\title{
Moral Questions and Dilemmas: Early Times to Present Day Issues
}

\author{
Michael W. Small and Geoffrey A. Trowbridge \\ Curtin University of Technology, Australia
}

\begin{abstract}
The purpose of this paper was to look at developments which have occurred in ethical behaviour in a nation's armed forces. The paper begins with the Greeks and their concept of arête 'manly virtue', and concludes with reference to courses in ethics conducted in various military academies. In Australia, the Department of Defence and the RAN have played a role in developing codes of conduct for all ranks, from senior officer to junior recruit. The paper suggests that developing an understanding of ethics in a military/naval context should be addressed at four levels. Criteria should be identified for identifying relevant ethical behaviour; agreement should be reached about what constitutes ethical behaviour; programs should be developed at recruit and officer cadet level; and finally, curricula in military/naval ethics should be an integral part of the program in military training establishments.
\end{abstract}

\section{Keywords}

Moral reasoning; core beliefs; codes of behaviour; codes of conduct,; a just war; rules of engagement; moral dilemmas.

\section{Introduction}

Should a country's armed forces have an understanding of the terms 'ethical behaviour, and codes of conduct', and should they be concerned with matters that some would argue are really ethical or moral issues? Well, it seems they should. In recent times, and with the help of recent media scrutiny, the relevance of this type of approach to some issues within the Australian Defence Force (ADF) has become more obvious.

The Vietnam War was the first war in which video from the battlefront was delivered via satellite in time for the evening news allowing unparalleled scrutiny of ethical and moral aspects of warfare. The advent of personal video cameras and mobile phones enhanced this capability to a very personal level. War correspondents and combat cameramen are now 'embedded' with fighting units and can tell much more visually than by words alone.

Events and situations which involve a moral and ethical component have been occurring throughout

Copyright (C) 2009 Victoria University. This document has been published as part of the Journal of Business Systems, Governance and Ethics in both online and print formats. Educational and non-profit institutions are granted a nonexclusive licence to utilise this document in whole or in part for personal or classroom use without fee, provided that correct attribution and citation are made and this copyright statement is reproduced. Any other usage is prohibited without the express permission of the history in the fighting forces of many nations. In Western Europe for example, some of these incidents are described in the myths and legends of ancient Greece and Rome, and some in stories told in the Old Testament.

The military archetype of the moral warrior is recorded in the song: 'Some talk of Alexander and some of Hercules, of Hector 
and Lysander and such great men as these'. To these, the names of Achilles, Ajax, Agamemnon, Ulysses (Odysseus) and Aeneas could be added. These persons, most of whom are probably mythical, appear in early Greek history, with the exception of Aeneas who appears in Virgil's (Latin) Aeneid. Bury (1956, pp. 50-53) has described in detail the world of the eighth century, i.e. the beginnings of Greece and the heroic age.

Who were these people and why do we still have an interest in them? In brief, they were warlords, and they had several characteristics in common. One was a close connection with the sea, another was to exhibit ethical and moral correctness in time of war and when undertaking noble deeds and acts of chivalry.

Each of them hero, warrior, general or admiral was well aware of the code of behaviour that was expected of persons of their class. The guiding principle in their code was the idea of arête (translated from the Greek as 'virtue, goodness, excellence of any kind, valour, manly beauty, dignity'). Their codes of behaviour were based on values or core beliefs that are recognizable today; viz., integrity, honour, duty, loyalty, fairness, respect and caring. Small (2002, pp. 401-407) has argued that moral values such as trust, honesty and integrity are important in organisations and if ignored then organisations would find it hard to survive and prosper.

These values are promoted in military training programs today, including Australia's Defence Forces. The historical warrior's gentlemanly stance and view of war as a biological necessity may not so easily be translated into the present century. In the present age, a more egalitarian approach to ethical decision making could be subsumed under the political decision to undertake a 'just war'; i.e. the moral undertaking of a soldier's involvement in war is decided by the political arm of a society.

\section{A Moral Issue}

War defined here as a state of armed conflict between two or more sovereign nations involves a state of open hostility and the contravening of international law. It is a violent method of determining who holds the power and who controls the wealth and resources. War is a matter of actual, intentional and widespread conflict to determine whose ideals will prevail. Consequently, because war is ugly, paradoxical and inexplicable, it creates massive social change. More importantly, war raises moral questions for society such as 'is it wrong to go to war?' Can war ever be justified? What rights and responsibilities do the members of a society have when their society goes to war?

Theories relating to ethical behaviour in war include realism, pacifism, and 'just war' arguments. 'Realism' is sceptical about moral concepts being relevant to issues related to foreign policy. Instead, societies should concentrate on internal security and economic growth. 'Pacifism' takes the view that moral concepts about war are relevant, but using a normative approach argues that war should never be undertaken. 'Just war' arguments contend that states can have a moral reason for going to war i.e., the reason for war can be justified and is morally right.

A war is said to be just if it follows a set of moral and legal guidelines. Cicero (106-64 BC) argued in favour of the use of military force when necessary. He stated that force could be justified when war was declared by a legitimate government. For example, Cicero as consul persuaded the Senate to protect the state by the resolution, videant consules ne quid res publica detrimenti capiat 'let the consuls see to it that the state suffer no harm'. Cicero with this authority was able to move gladiators to Capua, mobilise the municipal levies and order the praetor Metellus Celer to organise new forces in Northern Italy (Cicero, 1964, p. xviii; Cary, 1954, p. 372).

The concept of a 'just war' also appears in Saint Paul's early Christian writings. St. Augustin (353430) took the view that the only reason which justified war was the peace that followed. St. Thomas Aquinas (1225-1274) expanding on the ideas of St Augustin argued that there were three basic conditions which had to be met viz. (i) the war was prosecuted by a lawful authority; (ii) the war was undertaken with just cause; and (iii) the war was undertaken with the right intention. Hugo Grotius (1583-1645) the Dutch 'father and pioneer of international law' argued on the right of nations to use 
force in self-defence. In 1649, Parliament in England briefed the barrister, John Cooke, to conduct the first trial of a Head of State for waging war on his own people (Robertson, 2006). This 'just cause' was a forerunner of the prosecutions of Pinochet, Milosevic and Saddam Hussein.

So how did the current Laws of War originate? In 1899, an International Conference codified the rules of warfare and established the Permanent Court of Arbitration. In 1919, the League of Nations was established under the Treaty of Versailles to promote international cooperation and to achieve peace and security, but ceased its activities after failing to prevent the Second World War.

The United Nations came into existence on 24 October 1945, and a new regime of international law was instituted. Its provisions on laws of war adopted by the General Assembly are codified in the UN Charter, the Geneva Conventions and the Nuremberg principles. That Charter bars the threat or use of force unless authorised by the Security Council or, under Article 51, in self-defence against armed attack. However, while the UN is generally regarded as the ultimate authority, it should be noted that the majority of members are not democracies. It failed to prevent genocide in Kosovo, Rawanda and Sudan, and it failed to prevent massacres in Afghanistan and East Timor. In what can be considered justifiable humanitarian acts, India invaded East Pakistan in1971to end the mass slaughter of civilians; and Vietnam invaded Cambodia in 1978 to end Pol Pot's regime without reference to the UN.

\section{Just War Theory}

There are two fundamental principles that constitute the foundation of the 'Just War Theory'. The first is that actions are evaluated in terms of the range of likely consequences. A second is the principle of universality; we apply to ourselves the same standards we apply to others, if not more stringent ones. These principles are scalable and apply at the macro level as equally as they do at the individual level. The first test of any of any policy, legal, procedural or quality system is to acknowledge that the record on which defendants or systems are judged is the record on which history will judge us in the future the Nuremburg principle.

So it is possible to compare the world reaction to the Armenian genocide, India's occupation of Goa, the Indonesian 'liberation' of Netherlands New Guinea, the Chinese invasion of Tibet, the Angolan war of national liberation, the Iran-Iraq War and the Kosovo War with the U.S. invasion of Iraq. The U.S. National Security Strategy of September 2002 contradicted the fundamental principle of universality, and thereby challenged us to reconsider what was 'just' and 'proper' in reaction to terrorism that crossed national boundaries.

To date, the 'Just War Theory' as it has since become known is divided into three parts, Jus ad Bellum, Jus in Bello and Jus post Bellum. The document is presented in Latin, and gives the impression of having its origins in early Greek or Roman times. However, the term emerged only after World War II.

Part i. Jus ad bellum. Jus ad Bellum refers to the justice of the arguments in the phase leading up to a war. An example could be the debate and subsequent analysis in respect to Weapons of Mass Destruction (WMDs) prior to the commencement of the Iraq campaign. Were there WMDs or were there not? Six criteria would have had to have been met before war, or any form of military action could be justified. To illustrate: (i) was there a just cause, such as self-defence, against an armed attack? (ii) Was there a right intention in prosecuting the war? (iii) Did a proper authority sanction the slide towards a declaration of war? (iv) Was the war likely to be successful? (v) Was this the last resort? Had all non-violent options been exhausted? (vi) Were the benefits worth all the costs? Would the peace after the war be preferable to the situation without the war? Just war theory emphasizes that each and every one of the six criteria must be fulfilled for a particular declaration of war to be justified.

In respect to the Iraq war, there remains a lack of consensus in the community about the responses to some of these criteria. The concern is that the criterion of a legitimate authority, which has traditionally conferred the power to wage war upon heads of state, is called into question where the conflict is with, or between, organisations that are not nation-states. For some irrational, nihilistic groups, terrorism is 
their only option and the distinction between combatant and civilian, between one group's religious zeal and another's moral vision is blurred, confused and irreconcilable with 'just war' criteria.

Part ii. Jus in Bello. Jus in Bello refers to the justice of conduct within war, i.e. after the war has begun. One example could be the atrocities committed by Bosnian-Serb and Serb forces on Moslem prisoners during the Yugo-Slav war of the 1990s. Radovan Karadzic, a Bosnian-Serb, was arrested in July 2008 after thirteen years eluding justice. Ratko Mladic, the Bosnian-Serb general, is still being pursued for war crimes. Ante Gotovina, a general on the Croat side, was apprehended and is now facing the International Court in Holland. A just war approach would expect that such persons suspected of war crimes would be pursued and held accountable for their actions.

For the most part, the age of chivalry is still with us. Soldiers are expected to follow a number of conventions/rules in respect to the way they carry out their duties; viz. all international law prohibitions on weapons should be obeyed. Blinding lasers, landmines and cluster weapons are examples of weapons being actively proposed for prohibition. Chemical weapons are banned by many treaties, whereas nuclear weapons are not so clearly prohibited. The principle of discrimination recognises the civilian population which should be respected as non-combatants and left alone. The use of force should be moderated according to the amount needed to achieve the goal of the skirmish.

We are now in age where more damage may be done via a keyboard and remote controls than a bomb. The 'net-centric warfare' that provides filtered data, imagery and intelligence from multiple sources to and from the front line soldier/sailor/airman facilitates unprecedented responses that can be horribly wrong. Combatants should not engage in mala in se, using weapons or methods which are 'evil in themselves' e.g. mass rape, ethnic cleansing and using biological weapons. Combatants should avoid inhuman retaliation, and should provide benevolent quarantine for prisoners of war because enemy personnel taken prisoner are no longer engaged in doing harm.

Jus in Bello requires that the state, even though it is engaged in a war, must respect the human rights of its own citizens and military forces, and not merely concentrate on the enemy. Legitimate questions are whether or not traditional civil liberties should be curtailed in wartime, and can military personnel refuse to take part in operations they believe to be unjust? For example, Israel's policy in withdrawing from the Gaza strip and other occupied areas (August 2005) has presented some of its military personnel with a moral dilemma. Another example of a moral dilemma for commanders is the consequence of the Bush doctrine that 'those who harbor terrorists are as guilty as the terrorists themselves and must be attacked and destroyed' (Speech 7 October 2002).

Part iii. Jus post Bellum. Jus post Bellum refers to the level of justice after a war is terminated, and to peace treaties which are drawn up after war has finished. The Treaty of Versailles (1919) imposed harsh conditions on Germany after the Great War. To illustrate, Germany lost the territories of Alsace and Lorraine which were returned to France, Malmédy went to Belgium, Luxemburg was freed from German control, part of Schleswig went to Denmark, and all the overseas territories went to Britain or her dominions to France and Japan. The financial conditions imposed by the Allies were also harsh, and are said to have been, in part, causes of the 1939-1945 war. For example, after the Great War, Germany had to recompense France and Belgium for war damage, transferring livestock, coal and ships as reparation.

The jus post bellum expectations include a formal apology from the vanquished, and submission to reasonable punishment. War crimes trials, the executions of key military figures (e.g. Japanese General Tojo, and German Generals Keitel and Jodl), and rehabilitation were all legitimate part of the jus post bellum process. In the Japanese occupied territories alone, over 900 Japanese were executed after WW II.

Rehabilitation in respect to the Croatian/Serbian/Moslem conflict of the 1990s is being carried out, but revenge, punishment and undue hardship against a civilian population are strictly forbidden. These were ignored during that period. 
The regulating of terms and procedures of a just peace are necessary in the settlement of the war. There is a need for an ethical strategy, as well as a military strategy, for the concluding of hostilities so as not to provoke parties into resuming the dispute.

Principles for a jus post bellum period can include the vindication of rights. Revenge is inappropriate, but the cessation agreement should secure the rights of those whose violation triggered the war. Settlements not only should be reasonable, but should be seen to be reasonable by all concerned. Political leaders, military leaders and rights violators should be held accountable leading to a fair and public international trial where appropriate. Compensation or some form of financial restitution may be considered a part of rehabilitation. However, the most controversial aspect of reform relates to the expected structural transformation of a regime to a minimally just state. Another controversial aspect of reform relates to the U.S. and its allies firstly supporting and then opposing certain leaders with apparent disdain for their citizens e.g. Ceausescu, Suharto, Marcos, Duvalier, Chun, Mobutu, Somoza, Saddam Hussein, Aristide and most recently Mugabe.

In effect, the Just War Theory offers practical rules to guide decision makers on the appropriateness of their conduct before, during and after a war; especially in the case of a defensible war fought in a morally controlled fashion and completed in a responsible manner.

\section{Training in Moral Reasoning and Ethical Theory}

Military and naval academies in the United States now include courses in moral reasoning and ethical theory. Topics raised many years ago by the Stoics, Aristotle, St. Thomas Aquinas, Immanuel Kant, Jeremy Bentham, John Stewart Mill and John Rawls are included. In February 1998, the U.S. Naval Academy established the 'Center for the Study of Professional Military Ethics' in which military and naval ethical issues are analysed. This type of facility is now in place in the Australian Defence Force Academy (ADFA).

Since the second world war, the ultimate authority of the nation state has been superseded by social structures accepting international political structures under which national military forces are employed e.g. United Nations Peacekeeping Forces, NATO and the 'Coalition of the Willing'. Within these, the fighting men are bound to obedience of the state they serve. There are circumstances in which men or women find themselves under moral compulsion to refrain from what they are lawfully ordered to do. Conflicts of loyalties can and do arise, for example General Douglas MacArthur and President Charles de Gaulle, could both have been open to a charge of treason. In Vietnam and the Middle East, disobedience on grounds of conscience has arisen when the military has diverged from the ethical mores of the parent society. Modern warfare has evolved into limited wars fought for limited ends. The nationin-arms is no more. And so it is to be expected that discussion of topics within an ethical framework takes place at ADFA. For example, topics include: Analytical and Critical Thinking, What are ethical decisions? Values in the Australian Defence Force; The Nature of Just and Unjust Wars; The Ethical Military Officer; Permitted and Prohibited Weapons; Ethical Dilemmas, Issues of Military Life. The central philosophical/moral question underlying the ADFA discussions is: What ought one do in certain situations? At the recruit training level, the emphasis is on producing a 'thinking' soldier.

Members of a nation's defence force can sometimes find themselves in difficult and stressful situations e.g. ADF personnel who are part of regional assistance programs, peacekeeping and military deployments. Many of the decisions they make in these engagements will have a moral component, and these will need to be addressed in the Rules of Engagement.

\section{Rules of Engagement}

Most countries have principles, policies and standard operating procedures that define when, where and how force may be used. Military personnel are also given additional rules of engagement before performing any mission or military operation. The rules provide a consistent, understandable and repeatable standard on how forces will act in anticipated circumstances. They are thought out in detail 
in advance of an engagement and usually cover a number of scenarios, with different rules for each. U.S., U.K. and Australian armed forces provide their soldiers, sailors and airmen with rules that prescribe:

- The right to use force in self-defence and to match the level of response to the level of the threat;

- Actions they may take without consulting a higher authority, unless explicitly forbidden;

- Actions that may only be taken if explicitly ordered by a higher authority. The constant dilemma for the military is how to resolve two competing goals; the need to use force effectively to accomplish the mission objectives and the need to avoid unnecessary force.

- Actions that should be taken to fulfil a Commander's intent in the event of temporary loss of communications, command or control.

\section{Moral Dilemmas in Time of War}

Situations which describe the moral conflicts and the moral dilemmas which arise in wartime are often written into film sequences or narratives, but have a reality nevertheless. Following the Rules of Engagement, any individual may be held accountable for his/her actions in a split second response involving life and death considerations. Monsarrat (1953) described a tense scene moments after LtCommander George Ericson R.N.R., Captain of Compass Rose had released depth charges among forty survivors from a sunken ship. This was not only a moral issue for Lt.-Commander Ericson; it was also a dilemma; meaning it was a situation in which two choices (hence the expression 'on the horns of a dilemma') were available to the subject. Unfortunately both of these choices would have unsatisfactory outcomes. Ericson had the difficult choice of (i) attempting to rescue the forty survivors who were calling out to him and thereby putting his own ship at risk. Or (ii) he could attempt to sink the U-boat which he assumed had sunk their ship, thereby killing the survivors who were struggling in the water. Whichever way he responded, the best outcome was going to be less satisfactory than he would have liked, and the worst-case the outcome would have been catastrophic.

During the 1982 Falklands campaign, the Argentine cruiser General Belgrano was sunk by the hunterkiller submarine HMS Conqueror. General Belgrano was outside the 200 mile exclusion zone, but a (moral) decision was made to sink the Argentine warship because it was believed she posed a threat to operations in the Falklands. Conqueror fired two torpedoes, and the General Belgrano sank on the 2nd May 1982. On this occasion, 723 of the crew were rescued, but 368 were lost. Reeve cited in Reeve \& Stevens (2003, p. 21) has described the realities of being torpedoed and drifting in sub-Antarctic waters.

It appears that accepted rules and values change in times of war. Stevens cited in Reeve \& Stevens (2003, p. 263-264) summarises Admiral Sir John Fisher's general rule as: (i) Give no quarter; (ii) Take no prisoners; (iii) Sink everything; (iv) No time for mercy. Therefore, the question becomes one of whether, and to what degree can a moral position be established. Is it possible for personnel to maintain an ethical and moral standpoint when they enlist in their nation's armed forces? The answers to this question and the dilemmas which occur in military situations have been portrayed in the media recently. They show officers in a number of war zones in which the wars were not universally supported at home.

Personnel in today's ADF are expected to adhere to values such as: integrity, honour, duty, loyalty, fairness, respect and caring. The Department of Defence, as the co-ordinating government department charged with maintaining the nation's defence assets uses the mnemonic implicit to identify the values required throughout the Department. The term becomes more meaningful when written as imPLICIT, professionalism, loyalty, innovation, courage, integrity and teamwork.

The Navy has developed a similar values-framework based on the letters HHCIL; a mnemonic related to the Department of Defence's code. Honour, the fundamental value on which the Navy's reputation and that of individuals depends; the second $\mathrm{H}$ stands for Honesty, for always being truthful and knowing and doing what is right. Courage, the strength of character and doing what is right in the face of personal adversity, danger or threat. Integrity refers to truth, honesty and fairness. Integrity gains respect and 
trust from others. Loyalty refers to commitment to each other and to one's duty of service to Australia. The submarine service has added one other to the Navy list viz. esprit de corps. While not strictly a value, esprit de corps seems to be appropriate for the special role that submariners play in the defence of Australia. Gordon cited in Reeve and Stevens (2003, pp. 39-41) has listed nine examples of 'inspired command' from Nelson in 1797 to some of the decisive naval battles of WW II.

It could be argued that the promotion of specific values, whilst good in intent, does not achieve the same positive outcome as an examination which leads to the practice of high ethical behaviours. Values are not ethics. Ethics identifies the rules by which situations are judged to determine the degree to which the outcomes are acceptable and consequently of value. Thus, one may test one's values by referring to a series of widely accepted slogans viz., the Golden Rule, the Utilitarian Principle, the Categorical Imperative, the professional ethic, the media test, the legal test, and the Rotary four way test,

The Golden Rule states that a person should always act in a way you would expect others to act towards you. The idea of the Golden Rule is found in Matthew 7: 12, and Luke 6: 31. It also appears in the writings of others who were concerned with leading a good life. The Utilitarian Principle, Jeremy Bentham (1748-1832) and John Stuart Mill (1806-1873), states that one should always act in such a way as to produce the greatest good for the greatest number; i.e. the good of individuals is the ultimate value. It could be argued that the principle which seeks the greatest good for the greatest number could be justified in a war situation with a soldier's actions being considered ethical when, although an incident may not be good for the enemy, it was beneficial to large numbers of other people. The Categorical Imperative (Immanuel Kant) states that one ought never to act in such a way that the ethical maxim could not be a universal law; i.e. we should act in such a way that the action taken could be a universal law or rule of behaviour.

Even in a war zone, a rule allowing killing would not be a good universal law, although arguments may be made for the situation of war being a special case scenario. The professional ethic is a way of saying that any actions taken would need to be viewed as professional by a panel of one's peers. It is arguable that a review panel of peers would find a military person's actions admissible and acceptable when they had obeyed their lawful instructions and followed procedures established during their training. The media test raises questions such as would, for example, senior ADF personnel feel comfortable being on TV or on the front page of a newspaper to explain why s/he took a particular action? Given the code of silence that had surrounded reports of unethical actions in respect to a number of suicides among recruits undergoing training until very recently, it could be assumed that this is a powerful and useful test, and that the examples of the unethical behaviour would be identified. The legal test raises questions such as were the actions that the person took legal? It could be argued that if a war is legal, then that argument may be sufficient for some personnel. However, others would argue that the legal test is not sufficient and does not guarantee that war zone actions are ethical. The Rotary four way test is a composite set of criteria that summarises some of the key issues about an event. Four questions are asked: (i) was the decision truthful? (ii) Is the decision fair to all concerned? (iii) Will the actions build goodwill? (iv) Will the actions be beneficial to all concerned? It could be argued that only one answer in the negative would be sufficient to label an event unethical. Applying such criteria to actions taken in wartime does present difficulty.

In some cases a criterion could be seen to be supportive of certain actions taken, whereas in other examples such as the media test and the four way test, there would be difficulty in justifying certain actions.

\section{Conclusion}

The paper begins with a reference to the Ancient Greeks and their of concept of arête (manly virtue). This period occurs c. 800-700 (the rise of aristocracies) and c. 750-700 (Homer composes the Iliad and Odyssey). The paper includes an example from World War II, illustrating a moral dilemma; and to another decision taken in the recent Falklands campaign (1982). Reference was made to U. S. military and naval academies where military ethics are now an integral part of the curriculum. The Department 
of Defence and the RAN have played a key role in developing codes of conduct or behaviour for all ranks from senior executive to junior recruit. These can be summarised as imPLICIT for Defence, and HHCIL for the Navy. In summing up, ethics in war, and the ethics of war are complex subjects, both at the personal level and the professional level. Therefore developing an understanding of ethics and responding in an ethical way to military/naval issues should be addressed at four levels. (i) Criteria should be identified for identifying relevant acceptable and ethical behaviour. (ii) Agreement should be reached about what constitutes ethical behaviour. (iii) Programs should be developed at recruit and officer cadet level, and (iv) curricula in military/naval ethics should be an integral part of the curriculum in institutions responsible for training a nation's defence forces.

\section{Acknowledgements}

The writers acknowledge:

Commodore M.E. Deeks RAN CSC and Dr S. Coleman, ADFA for their generous contributions of time and resources in preparing sections of this paper.

\section{References}

Bury, JB 1956, History of Greece to the Death of Alexander the Great, Macmillan \& Co., London, pp. $50-53$

Cary, M 1954, A History of Rome Down to the Reign of Constantine, $2^{\text {nd }}$ edn. Macmillan \& Co., London, p. 372.

Cicero, 1964, First and Second Speeches Against Catiline, Macmillan \& Co., London, p. xviii.

Monsarrat, N 1953, The Cruel Sea, Cassell, London, p. 194.

Reeve, J \& Stevens D (eds.) 2003, The Face of Naval Battle The human experience of modern war at sea. Allen \& Unwin: Crows Nest, NSW, pp. 21, 39-41, 263-264.

Robertson, G 2006, The Tyrannicide Brief, Chatto \& Windus, Vintage.

Small, MW 2002, 'Practical Problems and Moral Values: Things We Tend to Ignore Revisited', Journal of Business Ethics, Vol 39, No 4, September (II), pp. 403-404. 